\title{
ENHANCEMENT THE PRODUCTIVITY OF PROCESSING CATEGORY POTATO BY BIOCHAR
}

\author{
T. S. Roy ${ }^{1}$, B. R. Das ${ }^{1}$, N. Sultana ${ }^{1}$, R. Chakraborty $^{1}$ and M. S. Rahman ${ }^{2}$ \\ ${ }^{1}$ Department of Agronomy, ${ }^{2}$ Department of Bio Chemistry, ${ }^{4}$ Department of Agricultural Chemistry, \\ Faculty of Agriculture, Sher-e-Bangla Agricultural University, Bangladesh \\ Corresponding Author: tuhinsuvraroy@sau.edu.bd
}

(Received: 19 August 2021, Accepted: 30 October 2021)

Keywords: Tuber yield, French fry, biomass inoculation, potato

\begin{abstract}
The application of biochar may enhance the yield of potato for different processing categories. A field experiment was conducted at Sher-e-Bangla Agricultural University, Dhaka-1207, during the period from November, 2020 to April, 2021 to find out the response of biochar on yield of potato for different processing categories. The experiment comprised of Potato varieties (3): $\mathrm{V}_{1}$ : BARI Alu-29 (Courage), $\mathrm{V}_{2}$ : BARI Alu-28 (Lady Rosetta) and $\mathrm{V}_{3}$ : BARI Alu-25 (Asterix) and Biochar level (5): $\mathrm{B}_{0}: 0 \mathrm{tha}^{-1}, \mathrm{~B}_{1}: 2.50 \mathrm{tha}^{-1}$, $\mathrm{B}_{2}: 5.00 \mathrm{tha}^{-1}$ and $\mathrm{B}_{3}: 7.50 \mathrm{tha}^{-1}$ and $\mathrm{B}_{4}: 10 \mathrm{tha}^{-1}$. The study was laid out in a randomized complete block design with 3 replications. The results showed that biochar amendment could enhance the yield of processing category potato. The total yield and marketable yield of potato gradually increased with increasing biochar level. The results also revealed that the processing category potato viz., canned, chips and French fry potato yield progressively increased with advancing biochar level irrespective of varieties except dehydrated category. In case of marketable yield, BARI Alu-25 and BARI Alu-29 with biochar level 5 to $10 \mathrm{t} \mathrm{ha}^{-1}$ performed superior than other combinations and produced 19.50 to $21.30 \mathrm{t} \mathrm{ha}^{-1}$ which are 18.54 to $36.45 \%$ higher than without biochar. The combination of $\mathrm{V}_{2} \mathrm{~B}_{4}$ produced maximum canned $\left(8.10 \mathrm{t} \mathrm{ha}^{-1}\right)$ and dehydrated potato $\left(10.09 \mathrm{tha}^{-1}\right)$ but $\mathrm{V}_{3} \mathrm{~B}_{4}$ made significantly highest chips $\left(9.03 \mathrm{t} \mathrm{ha}^{-1}\right)$ and French fry $(5.70 \mathrm{t}$ ha $^{-1}$ ) potato, whereas, BARI Alu-29 and BARI Alu-28 did not produce any French fry category potato. However, the level of biochar of 5 to $10 \mathrm{t} \mathrm{ha}^{-1}$ could enhance processing category potato production. It may be concluded that potato growers may apply biochar along with recommended rate of other fertilizers for producing maximum processing category potato.
\end{abstract}

\section{Introduction}

Among the world top ten potato producing countries, Bangladesh ranked the $8^{\text {th }}$ position (FAOSTAT, 2019). Beside of area and production of potato in Bangladesh, the yield has also been increasing but, the quality of potato are very low in compared to those of the other leading potato growing countries like Belgium, France, USA, Denmark, the Netherlands, UK (FAOSTAT, 2019).

The addition of soil amendment is necessary to restore the fertility of the soil. Biochar is one of the soil amendments that can improve soil fertility (Ding et al., 2016; Hunt et al., 2010). Biochar is produced by pyrolysis of biomass under low or anaerobic conditions (Nair et al., 2014). It is a mixture of char and ash, but it is mainly (70-95\%) carbon rich material. Biochar have good effects on some soil physical properties such as reducing soil bulk density (Mukherjee and Lal, 2013 and Mankasingh et al., 2011), increases the water retention capacity (Karhu et al., 2011 and Vaccari et al., 2011) and increases soil pH, EC, CEC of acidity soil (Abewa et al., 2014) and reduces the necessity of inorganic fertilizers. Biochar also can be a direct source of nutrients for plants which contains $\mathrm{N}, \mathrm{P}, \mathrm{K}, \mathrm{Ca}, \mathrm{Mg}, \mathrm{S}$ and micronutrient. Mollick et al. (2020) reported that, the yield and processing quality of potato have been 
significantly influenced by the application of $7 \mathrm{t} \mathrm{ha}^{-1}$ of biochar in potato field. So, considering beneficial effect of biochar, the present investigation was undertaken to observe the performance of potato varieties for processing purposes under biochar treatments.

\section{Materials and Methods}

The experiment was conducted at the Agronomy Research Field, Sher-e-Bangla Agricultural University, Dhaka-1207 situated at $23^{\circ} 771116 \mathrm{~min}$. North latitude and $90^{\circ} 375884 \mathrm{~min}$. East longitude at an altitude of 8.6 meter above the sea level (Anon., 2004) during the period from November, 2020 to April, 2021.Top soil was silty clay in texture, soil $\mathrm{pH}$ was 5.6 and has organic carbon of $0.45 \%$. The experiment was consisted of two factors, i.e., factor A:Potato varieties (3): $V_{1}$ : BARI Alu-29 (Courage), $\mathrm{V}_{2}$ : BARI Alu-28 (Lady Rosetta) and $\mathrm{V}_{3}$ : BARI Alu-25 (Asterix); factor B: Biochar level (5): $\mathrm{B}_{0}: 0 \mathrm{t} \mathrm{ha}^{-1}, \mathrm{~B}_{1}: 2.50 \mathrm{t} \mathrm{ha}^{-1}, \mathrm{~B}_{2}: 5.00 \mathrm{t} \mathrm{ha}^{-1}$ and $\mathrm{B}_{3}: 7.50 \mathrm{t} \mathrm{ha}^{-1}$ and $\mathrm{B}_{4}: 10 \mathrm{t} \mathrm{ha}^{-1}$. Experiment was laid out in a Factorial Randomized Complete Block Design (RCBD) with 3 replications. Certified grade sprouted potato tubers were used as planting material. The experimental plot was fertilized by recommended doses of Urea $325 \mathrm{~kg} \mathrm{ha}^{-1}$. Triple Super Phosphate (TSP) $200 \mathrm{~kg} \mathrm{ha}^{-}$ ${ }^{1}$, gypsum $100 \mathrm{~kg} \mathrm{ha}^{-1}$, zinc sulphate $8 \mathrm{~kg} \mathrm{ha}^{-1}$ Mondal et al. (2011). The total amount of biochar was applied at 7 days before planting as per treatment. Seed tubers $(50-60 \mathrm{~g})$ were planted at $4-5 \mathrm{~cm}$ depth in soil on November 11,2020. All other intercultural operations and plant protection measures were taken as per when needed. Harvesting of potato was done on February 19, 2021 at 7 days after haulm cutting. The potatoes of each plot were separately harvested, bagged and tagged and brought to the laboratory. All yield and quality contributing parameters were recorded as per treatments. On the basis of weight, the tubers have been graded into marketable tuber $(>20 \mathrm{~g})$ and non-marketable tuber $(<20 \mathrm{~g})$. Marketable tubers were again separated into canned potato $(20-35 \mathrm{~mm})$ dehydrated potato $(35-45 \mathrm{~mm})$, chips potato $(45-75 \mathrm{~mm})$ and French fries potato $(>75 \mathrm{~mm})$ as per processing category (Marwaha et al., 2010).The data obtained for different characters were statistically analyzed following the analysis of variance techniques by using MSTAT-C computer package program. The significant differences among the treatment means were compared by Least Significant Difference (LSD) at 5\% level of probability (Gomez and Gomez, 1984).

\section{Results and Discussion}

Potato yield: Potato yield was significantly $(\mathrm{p} \leq 0.05)$ influenced by varietal variation and/or biochar level (Figures 1, $2 \&$ Table 1). Results of Figure 1 showed that, the $\mathrm{V}_{3}$ produced maximum yield followed by $\mathrm{V}_{1}$ and $\mathrm{V}_{2}$ produced the minimum one. BARI ALu-25 produced $20.79 \%$ higher yield more potato than BARI ALu-28. This might be due to genetic potentiality of potato cultivars. The results of our findings were also in line with the findings of Youseef et al. (2017) and Vakis (1990) who found that potato yield varied with varietal variation. The yield of potato progressively increased with increasing biochar levels (Figure 2). The $32.06 \%$ higher yield was obtained from $\mathrm{B}_{4}$ than $\mathrm{B}_{0}$. The higher yield might be attributed to vigorous plant growth, more tubers hill ${ }^{-1}$ and large sized tuber. Biochar as a soil conditioner it may have increased soil fertility, reduced nutrient leaching, increased microbial activity in soil, improved water holding capacity, and cation exchange capacity in both sandy and clay soils which facilitated better photosynthetic activities, partitioning of photosynthates to the sink (storage organ potato tuber) consequently increased yield and quality of crops. This may also be because biochar serves as a carrier substrate for nitrogen $(\mathrm{N})$ and other mineral nutrients which increase the effectiveness of biochar by retaining and preventing the leaching of $\mathrm{N}$ beyond the reach of plants The results of our findings were accordance with those of Youseef et al. (2017), Ding et al. (2016), Yang et al. (2015), who reported that biochar application enhanced the yield of potato. Potato yield was also significantly influenced by the interaction effect of variety and biochar level (Table 1). The highest potato yield ( $27.33 \mathrm{tha}^{-1}$ ) was obtained from the $V_{3} B_{4}$ which was statistically similar to $V_{3} B_{3}, V_{3} B_{2}$ and 
$\mathrm{V}_{1} \mathrm{~B}_{4}$ and the lowest $\left(17.78 \mathrm{tha}^{-1}\right)$ was obtained from the $\mathrm{V}_{2} \mathrm{~B}_{0}$. Treatment combination $\mathrm{V}_{3} \mathrm{~B}_{4}$ produced $53.71 \%$ higher yield than $\mathrm{V}_{2} \mathrm{~B}_{0}$.

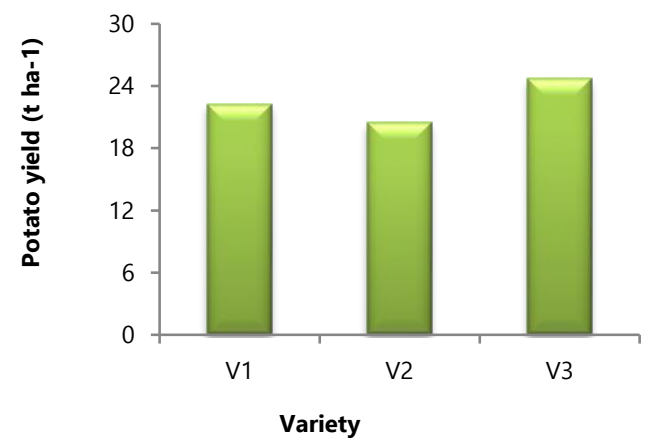

$\mathrm{V}_{1}$ : BARI Alu-29, $\mathrm{V}_{2}$ : BARI Alu-28 and $\mathrm{V}_{3}$ : BARI Alu-25

Fig. 1. Effect of variety on the potato yield $\left(\mathrm{LSD}_{0.05}=1.46\right)$

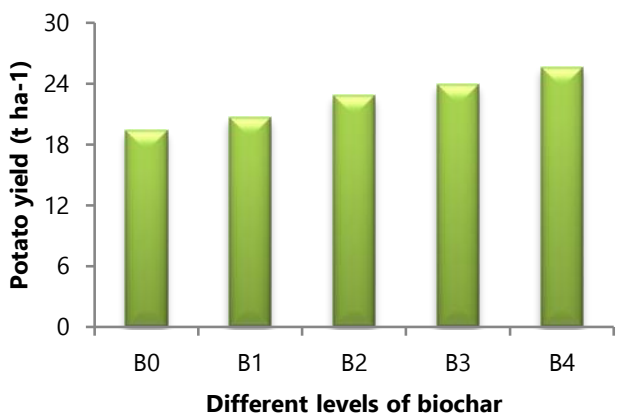

$\mathrm{B}_{0}: 0 \mathrm{tha}^{-1}, \mathrm{~B}_{1}: 2.5 \mathrm{tha}^{-1}, \mathrm{~B}_{2}: 5.0 \mathrm{t} \mathrm{ha}^{-1}$, $\mathrm{B}_{3}: 7.5 \mathrm{tha}^{-11}$ and $\mathrm{B}_{4}: 8.0 \mathrm{tha}^{-1}$

Fig. 2. Effect of biochar on the potato yield $\left(\operatorname{LSD}_{0.05}=1.89\right)$

Marketable potato yield: Marketable potato yield $(>20 \mathrm{~g})$ was significantly $(\mathrm{p} \leq 0.05)$ differed by different potato varieties (Figure 3). Results revealed that, the treatment $\mathrm{V}_{3}$ produced the maximum marketable potato followed by $\mathrm{V}_{1}$ and $\mathrm{V}_{2}$ whereas minimum. $\mathrm{V}_{3}$ produced $11.79 \%$ higher marketable potato than $\mathrm{V}_{2}$. Biochar level had significant influenced on the marketable potato yield (Figure 3).

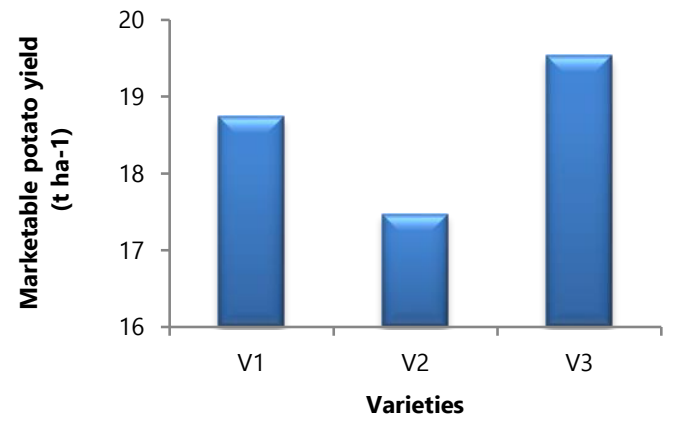

$\mathrm{V}_{1}$ : BARI Alu-29, $\mathrm{V}_{2}$ : BARI Alu-28 and $\mathrm{V}_{3}$ : BARI Alu-25

Fig. 3. Effect of variety on the marketable potato yield $\left(\mathrm{LSD}_{0.05}=0.98\right)$

Results revealed that, marketable potato yield gradually increased with increasing biochar levels and $\mathrm{B}_{4}$ produced maximum marketable potato which was statistically at par with $\mathrm{B}_{3}$ and $\mathrm{B}_{2}$ and $21.58 \%$ higher marketable potato yield was obtained from the plot treated with $10 \mathrm{t} \mathrm{ha}^{-1}$ biochar $\left(\mathrm{B}_{4}\right)$ than without biochar $\left(\mathrm{B}_{0}\right)$.Gautam et al. (2017), reported that higher levels of the biochar amended soils could be due to improved availability of phosphorous as a result of biochar addition which also could be the reason for better production of marketable potato. Collins et al. (2013) also reported that increased biochar application had increased quality potato tuber. Youseef et al. (2017) reported that marketable yield was significantly increased with increasing biochar application rates up to $5 \mathrm{~m}^{3} \mathrm{fed}^{-1}$.

Marketable potato yield was significantly differed by the interaction effect of variety and biochar level (Table 1). The maximum marketable potato yield $\left(21.30 \mathrm{tha}^{-1}\right)$ was obtained from the $\mathrm{V}_{3} \mathrm{~B}_{4}$ which was 
statistically at par with $V_{3} B_{3}, V_{3} B_{2}, V_{1} B_{2}, V_{1} B_{3}$ and $V_{1} B_{4}$ and the lowest marketable potato yield (15.61 $t h^{-1}$ ) from the $V_{2} B_{0}$ treatment combination which was statistically at par with $V_{1} B_{0}, V_{1} B_{1}, V_{2} B_{1}$, $\mathrm{V}_{2} \mathrm{~B}_{2}$ and $\mathrm{V}_{3} \mathrm{~B}_{0}$. Treatment combination $\mathrm{V}_{3} \mathrm{~B}_{4}$ produced $36.45 \%$ more marketable potato than treatment combination $\mathrm{V}_{2} \mathrm{~B}_{0}$. These results agree with those reported by Nair et al. (2014) who found that marketable potato yield increased with increasing biochar.

Table 1. Interaction effect of variety and biochar on the yield characters of potato

\begin{tabular}{ccc}
\hline Treatment combinations & Potato yield $\left(\mathbf{t ~ h a}^{-\mathbf{1}}\right)$ & Marketable potato yield $\left(\mathbf{t} \mathbf{~ h a}^{-\mathbf{1}}\right)$ \\
\hline $\mathrm{V}_{1} \mathrm{~B}_{0}$ & $19.15 \mathrm{~g}-\mathrm{i}$ & $16.45 \mathrm{de}$ \\
$\mathrm{V}_{1} \mathrm{~B}_{1}$ & $20.04 \mathrm{f}-\mathrm{i}$ & $17.50 \mathrm{c}-\mathrm{e}$ \\
$\mathrm{V}_{1} \mathrm{~B}_{2}$ & $22.83 \mathrm{c}-\mathrm{f}$ & $19.52 \mathrm{a}-\mathrm{c}$ \\
$\mathrm{V}_{1} \mathrm{~B}_{3}$ & $23.59 \mathrm{~b}-\mathrm{e}$ & $19.97 \mathrm{ab}$ \\
$\mathrm{V}_{1} \mathrm{~B}_{4}$ & $25.70 \mathrm{a}-\mathrm{c}$ & $20.24 \mathrm{ab}$ \\
$\mathrm{V}_{2} \mathrm{~B}_{0}$ & $17.78 \mathrm{i}$ & $15.61 \mathrm{e}$ \\
$\mathrm{V}_{2} \mathrm{~B}_{1}$ & $18.41 \mathrm{hi}$ & $16.52 \mathrm{de}$ \\
$\mathrm{V}_{2} \mathrm{~B}_{2}$ & $20.41 \mathrm{e}-\mathrm{i}$ & $17.75 \mathrm{c}-\mathrm{e}$ \\
$\mathrm{V}_{2} \mathrm{~B}_{3}$ & $21.75 \mathrm{~d}-\mathrm{g}$ & $18.52 \mathrm{~b}-\mathrm{d}$ \\
$\mathrm{V}_{2} \mathrm{~B}_{4}$ & $23.84 \mathrm{~b}-\mathrm{d}$ & $18.97 \mathrm{bc}$ \\
$\mathrm{V}_{3} \mathrm{~B}_{0}$ & $21.28 \mathrm{~d}-\mathrm{h}$ & $17.69 \mathrm{c}-\mathrm{e}$ \\
$\mathrm{V}_{3} \mathrm{~B}_{1}$ & $18.55 \mathrm{~b}-\mathrm{d}$ \\
$\mathrm{V}_{3} \mathrm{~B}_{2}$ & $23.49 \mathrm{~b}-\mathrm{e}$ & $19.50 \mathrm{a}-\mathrm{c}$ \\
$\mathrm{V}_{3} \mathrm{~B}_{3}$ & $25.05 \mathrm{a}-\mathrm{c}$ & $20.58 \mathrm{ab}$ \\
$\mathrm{V}_{3} \mathrm{~B}_{4}$ & $26.29 \mathrm{ab}$ & $21.30 \mathrm{a}$ \\
\hline $\mathrm{LSD}(0.05)$ & $27.33 \mathrm{a}$ & 2.19 \\
\hline $\mathrm{CV}(\%)$ & 3.27 & 7.05 \\
\hline
\end{tabular}

$\mathrm{V}_{1}$ : BARI Alu-29 (Courage), V2: BARI Alu-28 (Lady Rosetta) and V3: BARI Alu-25 (Asterix); Bo: $0 \mathrm{t} \mathrm{ha}^{-1}, \mathrm{~B}_{1}: 2.50 \mathrm{t}$ ha ${ }^{1}, \mathrm{~B}_{2}: 5.00 \mathrm{tha}^{-1}, \mathrm{~B}_{3}: 7.50 \mathrm{tha}^{-1}$ and $\mathrm{B}_{4}: 10 \mathrm{tha}^{-1}$.

In a column the mean having the same letter(s) don't differ significantly at 5\% level of [probability

Canned potato yield: Potato variety showed significant difference on canned potato yield (Figure 5). The highest canned potato $\left(6.74 \mathrm{t} \mathrm{ha}^{-1}\right)$ was produced by the $\mathrm{V}_{2}$ and the lowest canned potato (3.09 $\mathrm{t}$ by the $V_{3}$. Biochar levels exerted significant difference on canned potato yield (Figure 6). The highest canned potato $\left(6.04 \mathrm{t} \mathrm{ha}^{-1}\right)$ was produced by the $\mathrm{B}_{4}$ and the lowest canned potato $\left(3.96 \mathrm{t} \mathrm{ha}^{-1}\right)$ by the treatment $\mathrm{B}_{0}$. Interaction effect of variety and different biochar levels exerted significant difference on canned potato yield (Table 2). The highest canned potato $\left(8.10 \mathrm{t} \mathrm{ha}^{-1}\right)$ was produced by the treatment combination $\mathrm{V}_{2} \mathrm{~B}_{4}$ and the lowest canned potato $\left(2.46 \mathrm{t} \mathrm{ha}^{-1}\right)$ was produced by the treatment combination $\mathrm{V}_{3} \mathrm{~B}_{0}$ which was statistically similar with $\mathrm{V}_{3} \mathrm{~B}_{1}$.

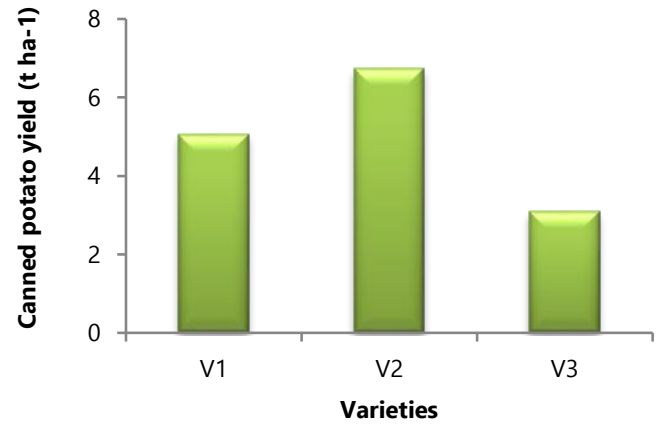

$\mathrm{V}_{1}$ : BARI Alu-29, $\mathrm{V}_{2}$ : BARI Alu-28 and $\mathrm{V}_{3}$ : BARI Alu-25

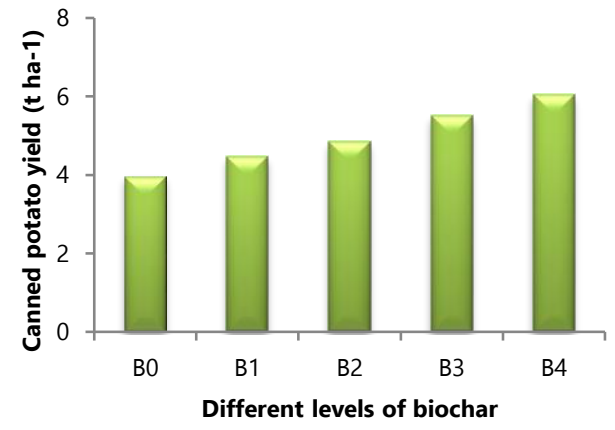

$\mathrm{B}_{0}: 0 \mathrm{tha}^{-1}, \mathrm{~B}_{1}: 2.5 \mathrm{tha}^{-1}, \mathrm{~B}_{2}: 5.0 \mathrm{tha}^{-1}, \mathrm{~B}_{3}: 7.5 \mathrm{tha}^{-11}$ and $\mathrm{B}_{4}$ : 10.0 tha $^{-1}$

Fig. 5. Effect of variety on the canned potato yield Fig. 6. Effect of biochar on the canned potato 


$$
\left(\operatorname{LSD}_{0.05}=0.34\right)
$$

yield $\left(\operatorname{LSD}_{0.05}=0.44\right)$

Dehydrated potato yield: Dehydrated potato yield was significantly $(\mathrm{p} \leq 0.05)$ differed by the varietal difference (Figure 7). The highest dehydrated potato yield $\left(6.39 \mathrm{t} \mathrm{ha}^{-1}\right)$ was recorded from the $\mathrm{V}_{2}$ followed by $V_{1}\left(6.35 \mathrm{t} \mathrm{ha}^{-1}\right)$ whereas the lowest one $\left(4.67 \mathrm{t} \mathrm{ha}^{-1}\right)$ was recorded from $\mathrm{V}_{3}$. Dehydrated potato yield was significantly differed by the different biochar levels (Figure 8). The highest dehydrated potato yield $\left(6.94 \mathrm{tha}^{-1}\right)$ was recorded from the $\mathrm{B}_{4}$ whereas the lowest one $\left(4.74 \mathrm{tha}^{-1}\right)$ was recorded from $\mathrm{B}_{2}$.

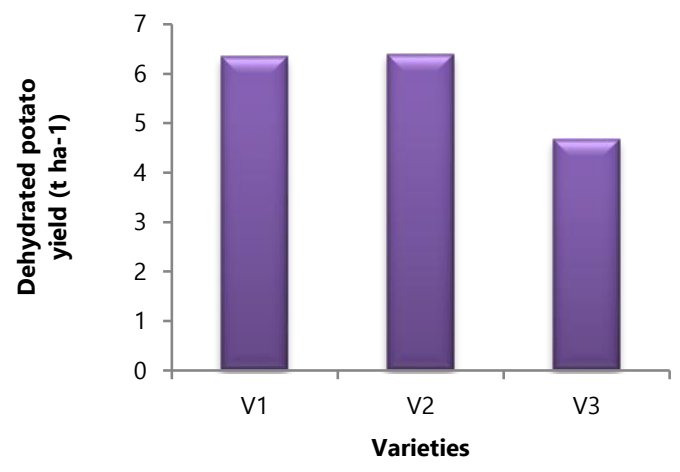

$\mathrm{V}_{1}$ : BARI Alu-29, $\mathrm{V}_{2}$ : BARI Alu-28 and $\mathrm{V}_{3}$ : BARI Alu-25

Fig. 7. Effect of variety on the dehydrated potato yield $\left(\operatorname{LSD}_{0.05}=0.49\right)$

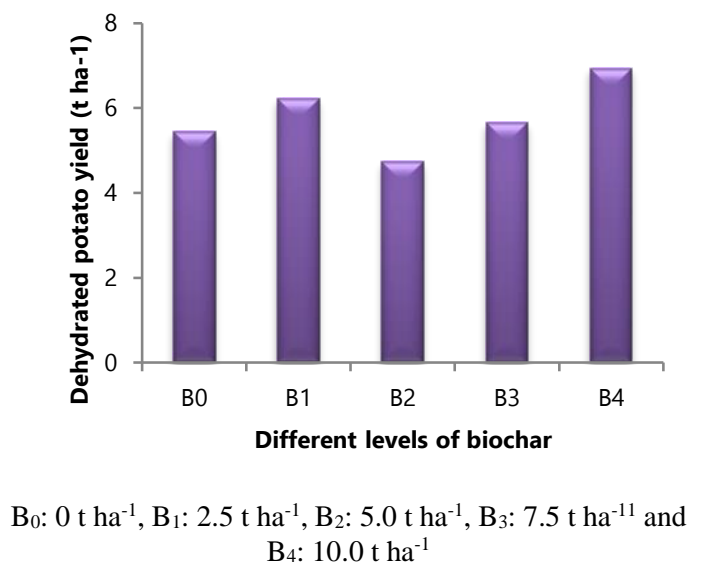

Fig. 8. Effect of biochar on the dehydrated potato yield $\left(\operatorname{LSD}_{0.05}=0.63\right)$

Dehydrated potato yield was significantly differed by the interaction effect of variety and biochar levels (Table 2). The highest dehydrated potato yield $\left(10.09 \mathrm{t} \mathrm{ha}^{-1}\right)$ was recorded from the treatment combination $V_{2} B_{4}$ whereas the lowest one (4.04 tha $a^{-1}$ ) was recorded from $V_{3} B_{2}$ which was statistically similar with $\mathrm{V}_{3} \mathrm{~B}_{4}, \mathrm{~V}_{3} \mathrm{~B}_{3}, \mathrm{~V}_{3} \mathrm{~B}_{1}$ and $\mathrm{V}_{2} \mathrm{~B}_{2}$.

Chips potato yield: Potato variety exerted significant influence on chips potato yield (Figure 9). The highest chips potato $\left(7.19 \mathrm{tha}^{-1}\right)$ was produced by the $\mathrm{V}_{3}$ and the lowest chips potato $\left(3.61 \mathrm{tha}^{-1}\right)$ was produced by the $\mathrm{V}_{2}$. Biochar levels employed significant influence on chips potato yield (Figure 10). The chips potato yield gradually increased with increasing biochar level.The highest chips potato (6.82 $\mathrm{t} \mathrm{ha}^{-1}$ ) was produced by the $\mathrm{B}_{4}$ and the lowest $\left(3.94 \mathrm{tha}^{-1}\right)$ by the treatment $\mathrm{B}_{0}$. Interaction effect of variety and different biochar levels exerted significant influence on chips potato yield (Table 2). The highest chips potato $\left(9.03 \mathrm{tha}^{-1}\right)$ was produced by the treatment combination $\mathrm{V}_{3} \mathrm{~B}_{4}$ and the lowest chips potato $\left(2.08 \mathrm{tha}^{-1}\right)$ was produced by the treatment combination $\mathrm{V}_{2} \mathrm{~B}_{0}$. Increases chips potato yield has been attributed to better water holding capacity, higher cation exchange capacity, increased aeration, increased nutrient retention and the ability of biochar to reduce bulk-density. Nair et al. (2014) stated similar comments regarding chips potato yield. 


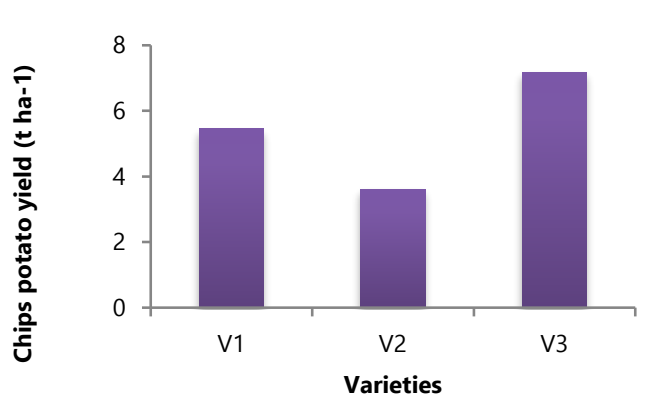

$\mathrm{V}_{1}$ : BARI Alu-29, $\mathrm{V}_{2}$ : BARI Alu-28 and $\mathrm{V}_{3}$ : BARI Alu-25

Fig. 9. Effect of variety on the chips potato yield $\left(\operatorname{LSD}_{0.05}=0.38\right)$

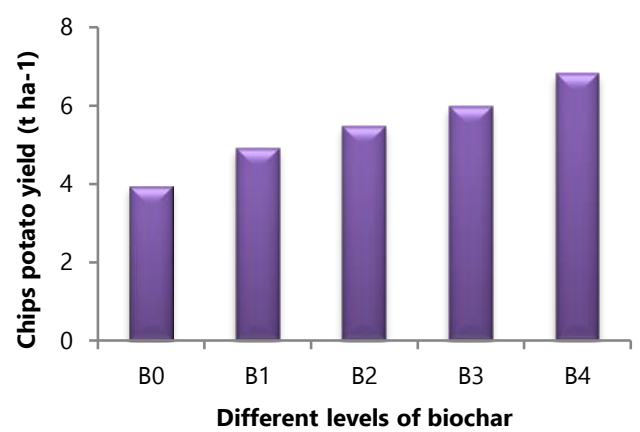

$\mathrm{B}_{0}: 0 \mathrm{t} \mathrm{ha}^{-1}, \mathrm{~B}_{1}: 2.5 \mathrm{tha}^{-1}, \mathrm{~B}_{2}: 5.0 \mathrm{tha}^{-1}, \mathrm{~B}_{3}: 7.5 \mathrm{tha}^{-11}$ and $\mathrm{B}_{4}: 10.0 \mathrm{tha}^{-1}$

Fig. 10. Effect of biochar on the chips potato yield $\left(\operatorname{LSD}_{0.05}=0.50\right)$

French-fry potato yield: French-fry potato yield was significantly influenced by the potato variety (Figure 23). The highest french-fry potato yield $\left(4.32 \mathrm{t} \mathrm{ha}^{-1}\right)$ was recorded from the $\mathrm{V}_{3}$ and both the variety $\mathrm{V}_{1}$ and $\mathrm{V}_{2}$ did not produce any french-fry potato. French-fry potato yield was significantly influenced by the different biochar levels (Figure 24). The results also revealed that french-fry potato yield increased with increasing biochar level. The highest french-fry potato yield $\left(1.90 \mathrm{t} \mathrm{ha}^{-1}\right)$ was recorded from the $\mathrm{B}_{4}$ treatment whereas the lowest $\left(0.99 \mathrm{t} \mathrm{ha}^{-1}\right)$ from $\mathrm{B}_{0}$ treatment. The increase in yield of potato for French fry production with the application of biochar could be attributed to corresponding increase in leaf area, which was responsible for synthesizing photosynthesis and increase in tuber weight (Youseef et al., 2017).

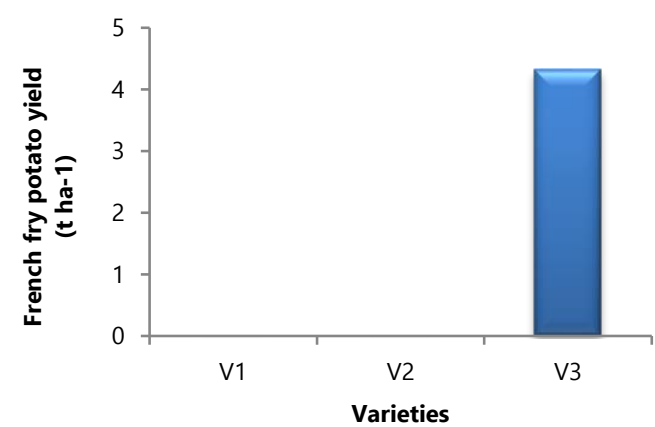

$\mathrm{V}_{1}$ : BARI Alu-29, V2: BARI Alu-28 and $\mathrm{V}_{3}$ : BARI Alu-25

Fig. 11. Effect of variety on yield of potato for French fry production $\left(\mathrm{LSD}_{0.05}=0.24\right)$

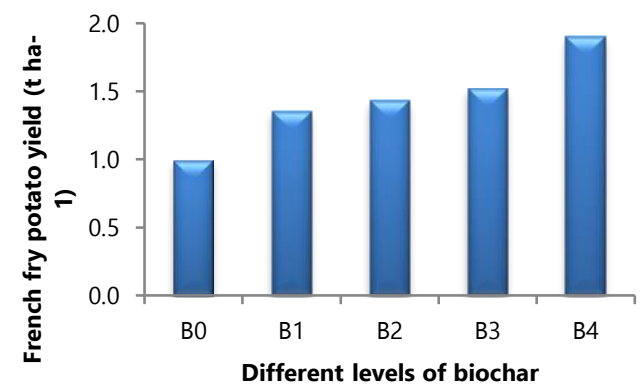

$\mathrm{B}_{0}: 0 \mathrm{t} \mathrm{ha}^{-1}, \mathrm{~B}_{1}: 2.5 \mathrm{tha}^{-1}, \mathrm{~B}_{2}: 5.0 \mathrm{tha}^{-1}, \mathrm{~B}_{3}: 7.5 \mathrm{tha}^{-11}$ and $\mathrm{B}_{4}: 10.0 \mathrm{tha}^{-1}$

Fig. 12. Effect of biocharon yield of potato for French fry production $\left(\operatorname{LSD}_{0.05}=0.30\right.$ )

French-fry potato yield was significantly influence by the interaction effect of variety and different biochar levels (Table 2). The highest french-fry potato yield $\left(5.70 \mathrm{t} \mathrm{ha}^{-1}\right)$ was recorded from the treatment combination $\mathrm{V}_{3} \mathrm{~B}_{4}$ whereas $\mathrm{V}_{1}$ and $\mathrm{V}_{2}$ in combination with all the biochar levels did not produce any french-fry potato.

Table 2. Interaction effect of variety and biochar on yield of potato for different processing purpose

\begin{tabular}{ccccc}
\hline $\begin{array}{c}\text { Treatment } \\
\text { combinations }\end{array}$ & $\begin{array}{c}\text { Yield for canned } \\
\text { potato production } \\
\left(\mathrm{t} \mathrm{ha}^{-1}\right)\end{array}$ & $\begin{array}{c}\text { Yield for Dehydrated } \\
\text { potato production } \\
\text { yield }\left(\mathrm{t} \mathrm{ha}^{-1}\right)\end{array}$ & $\begin{array}{c}\text { Yield of potato for } \\
\text { chips production } \\
\left(\mathrm{tha}^{-1}\right)\end{array}$ & $\begin{array}{c}\text { Yield of potato } \\
\text { for French fry } \\
\text { production }\end{array}$ \\
\hline
\end{tabular}




\begin{tabular}{ccccc}
\hline & & & & $\left(\mathbf{t ~ h a} \mathbf{a}^{-1}\right)$ \\
\hline $\mathrm{V}_{1} \mathrm{~B}_{0}$ & $3.87 \mathrm{fg}$ & $5.64 \mathrm{~cd}$ & $4.43 \mathrm{f}-\mathrm{h}$ & $\mathrm{NF}$ \\
$\mathrm{V}_{1} \mathrm{~B}_{1}$ & $4.43 \mathrm{ef}$ & $7.22 \mathrm{~b}$ & $5.09 \mathrm{ef}$ & $\mathrm{NF}$ \\
$\mathrm{V}_{1} \mathrm{~B}_{2}$ & $4.70 \mathrm{e}$ & $5.62 \mathrm{~cd}$ & $5.52 \mathrm{e}$ & $\mathrm{NF}$ \\
$\mathrm{V}_{1} \mathrm{~B}_{3}$ & $5.82 \mathrm{~cd}$ & $6.75 \mathrm{~b}$ & $5.73 \mathrm{de}$ & $\mathrm{NF}$ \\
$\mathrm{V}_{1} \mathrm{~B}_{4}$ & $6.48 \mathrm{c}$ & $6.49 \mathrm{bc}$ & $6.55 \mathrm{~cd}$ & $\mathrm{NF}$ \\
$\mathrm{V}_{2} \mathrm{~B}_{0}$ & $5.55 \mathrm{~d}$ & $5.47 \mathrm{~cd}$ & $2.08 \mathrm{j}$ & $\mathrm{NF}$ \\
$\mathrm{V}_{2} \mathrm{~B}_{1}$ & $6.38 \mathrm{c}$ & $6.44 \mathrm{dc}$ & $3.15 \mathrm{i}$ & $\mathrm{NF}$ \\
$\mathrm{V}_{2} \mathrm{~B}_{2}$ & $6.40 \mathrm{c}$ & $4.56 \mathrm{~d}-\mathrm{f}$ & $3.71 \mathrm{hi}$ & $\mathrm{NF}$ \\
$\mathrm{V}_{2} \mathrm{~B}_{3}$ & $7.26 \mathrm{~b}$ & $5.41 \mathrm{~cd}$ & $4.23 \mathrm{gh}$ & $\mathrm{NF}$ \\
$\mathrm{V}_{2} \mathrm{~B}_{4}$ & $8.10 \mathrm{a}$ & $10.09 \mathrm{a}$ & $4.88 \mathrm{e}-\mathrm{g}$ & $\mathrm{NF}$ \\
$\mathrm{V}_{3} \mathrm{~B}_{0}$ & $2.46 \mathrm{~h}$ & $5.21 \mathrm{de}$ & $5.30 \mathrm{e}$ & $2.98 \mathrm{c}$ \\
$\mathrm{V}_{3} \mathrm{~B}_{1}$ & $2.57 \mathrm{~h}$ & $5.05 \mathrm{~d}-\mathrm{f}$ & $6.47 \mathrm{~cd}$ & $4.06 \mathrm{~b}$ \\
$\mathrm{~V}_{3} \mathrm{~B}_{2}$ & $3.42 \mathrm{~g}$ & $4.04 \mathrm{f}$ & $7.19 \mathrm{bc}$ & $4.29 \mathrm{~b}$ \\
$\mathrm{~V}_{3} \mathrm{~B}_{3}$ & $3.44 \mathrm{~g}$ & $4.82 \mathrm{~d}-\mathrm{f}$ & $7.95 \mathrm{~b}$ & $4.55 \mathrm{~b}$ \\
$\mathrm{~V}_{3} \mathrm{~B}_{4}$ & $3.54 \mathrm{~g}$ & $4.23 \mathrm{ef}$ & $9.03 \mathrm{a}$ & $5.70 \mathrm{a}$ \\
\hline $\mathrm{LSD}(0.05)$ & 0.76 & 1.09 & 0.86 & 0.53 \\
$\mathrm{CV}(\%)$ & 9.18 & 11.19 & 9.46 & 21.87 \\
\hline
\end{tabular}

In a column the mean having the same letter(s) don't differ significantly at $5 \%$ level of probabilityV $\mathrm{V}_{1}$ : BARI Alu-29 (Courage), V2: BARI Alu-28 (Lady Rosetta) and $\mathrm{V}_{3}$ : BARI Alu-25 (Asterix); Bo: $0 \mathrm{t} \mathrm{ha}^{-1}, \mathrm{~B}_{1}: 2.50 \mathrm{t} \mathrm{ha}^{-1}, \mathrm{~B}_{2}: 5.00 \mathrm{t} \mathrm{ha}^{-1}$, $\mathrm{B}_{3}: 7.50 \mathrm{tha}^{-1}$ and $\mathrm{B}_{4}: 10 \mathrm{tha}^{-1}$. NF means not found.

\section{Conclusion}

From the above findings, it may be concluded that biochar had significant positive role on potato production. The marketable yield, canned, chips and French fry category potato yield sharply increased with increasing biochar level. Among the treatment combinations, BARI Alu-25 and BARI Alu-29 with biochar level from 5 to $10 \mathrm{t} \mathrm{ha}^{-1}$ produced significantly higher yield (19.50 to 21.30 $\mathrm{t} \mathrm{ha}^{-1}$ ) than other combinations which are 18.54 to $36.45 \%$ higher than without biochar. The combination of $\mathrm{V}_{2} \mathrm{~B}_{4}$ produced maximum canned $\left(8.10 \mathrm{t} \mathrm{ha}^{-1}\right)$ and dehydrated potato $\left(10.09 \mathrm{tha}^{-1}\right)$ but $\mathrm{V}_{3} \mathrm{~B}_{4}$ made significantly maximum chips $\left(9.03 \mathrm{t} \mathrm{ha}^{-1}\right)$ and French fry $\left(5.70 \mathrm{t} \mathrm{ha}^{-1}\right)$ category potato, whereas, no French fry category potato was found from BARI Alu-29 and BARI Alu-28 It may be concluded that potato growers could apply biochar along with recommended rate of other fertilizers for producing maximum processing category potato.

\section{Acknowledgements}

This study was supported by the Grant of Advanced Research in Education (GARE), Bangladesh Bureau of Educational Information and Statistic (BANBEIS), Ministry of Education, Government of the People`s Republic of Bangladesh.

\section{References}

Abewa, A., B. Yitaferu, Y.G. Selassie and T. Amare. 2014. The role of biochar on acid soil reclamation and yield of Teff (Eragrostistef [Zucc] Trotter) in Northwestern Ethiopia. J. Agric. Sci.6(1): 1-12.

Anonymous. 2004. Effect of seedling throwing on the grain yield of wart land rice compared to other planting methods.Crop Soil Water Management Program Agronomy Division, BRRI, Gazipur1710. p.56.

Chan, K., L. Van Zwieten, I. Meszaros, A. Downie and S. Joseph. 2008. Agronomic values of green waste biochar as a soil amendment. Soil Res. 45: 629-634.

Collins, H.P., J. Streubel, A. Alva, L. Porter and B. Chaves. 2013. Phosphorus uptake by potato from biochar amended with anaerobic digested dairy manure effluent. Agron. J. 105(4): 989-998. 
Cornelissen, G., V. Martinsen, V. Shitumbanuma, V. Alling, G.D. Breedveld, D.W. Rutherford, M. Sparrevik, S.E. Hale, A. Obia, J. Mulder, P.O. Boxand W.R. Division. 2013. Biochar Effect on Maize Yield and Soil Characteristics in Five Conservation Farming Sites in Zambia. pp.256-274.

Ding, Y., Y. Liu, S. Liu, Z. Li, X. Tan, X. Huang, G. Zeng, L. Zhou and B. Zheng. 2016. Biochar to improve soil fertility. A Review. Agron. Sust. Dev. 36(2): 1-18.

Dou, L., M Komatsuzaki, and M. Nakagawa. 2012. Effects of biochar, mokusakueki and bokashi application on soil nutrients, yields and qualities of sweet potato. Int. Res. J. Agril. Sci. Soil Sci.2(8): 318-327.

FAOSTAT.2019. Statistical Database. Food and Agricultural Organization of United Nations, Rome, Italy. Food Agric. 80: 810-820.

Gautam, D.K., R.M, Bajracharya and B.K. Sitaula. 2017. Biochar amendment of soil and its effect on crop production of small holder farms in Rasuwa district of Nepal. Int. J. Agric. Environ. Biores. 2(2): 120-135.

Gomez, K.A. andA.A. Gomez. 1984. Statistical procedure for agricultural research. Second Edn. Intl. Rice Res. Inst., John Wiley and Sons. New York. pp.1-340.

Hunt, J., M. DuPonte, D. Sato and A. Kawabata. 2010. The basics of biochar: A natural soil amendment. Soil Crop Manag. 30(7): 1-6.

Kang, S.W., J.W. Park, D.C. Seo, Y.S. Ok, K.D. Park, I.W. Choi and J.S. Cho. 2016. Effect of biochar application on rice yield and greenhouse gas emission under different nutrient conditions from paddy soil. J. Environ. Eng. 142: 1-7.

Karhu, K., T. Mattila, I. Bergström and K. Regina. 2011. Biochar addition to agricultural soil increased $\mathrm{CH}_{4}$ uptake and water holding capacity-Results from a short-term pilot field study. Agric. Ecosyst. Environ. 140(1-2): 309-313.

Mankasingh, U., P. Choi and V. Ragnarsdottir. 2011. Biochar application in a tropical, agricultural region: A plot scale study in. Appl. Geochem. 26: 218-221.

Marwaha, R.S., S.K. Pandey, D. Kumar, S.V. Singh and P. Kumar. 2010. Potato processing scenario in India: industrial constraints, future projections, challenges ahead and remedies-a review. J. Food Sci. Technol. 47(2): 137-156.

Mollick, M.O.A., A.K. Paul, I. Alamand M.M. Sumon. 2020. Effect of biochar on yield and quality of potato (Solanum tuberosum L.) tuber. Intl. J. Bio. Stress Manag. 11(5): 445-450.

Mondal, M.R.I., M.S. Islam, M.A.B. Jalil, M.M. Rahman, M.S. Alam and M.H.H. Rahman. 2011.KrishiProjuktiHatboi (Handbook of Agro-technology), $5^{\text {th }}$ edition. Bangladesh Agricultural Research Institute, Gazipur-1701, Bangladesh. p.307.

Mukherjee, A. and R. Lal. 2013. Biochar impacts on soil physical properties and greenhouse gas emissions. pp.313-339.

Mukherjee, A. and A.R. Zimmerman. 2013. Organic carbon and nutrient release from a range of laboratoryproduced biochars and biochar-soil mixtures. Geoderma.193: 122-130.

Nair, A., R.A.J.L. Kruse, Tillman and V. Lawson. 2014.Biochar application in potato production. Iowa State Res. Farm Prog. Rep. 2027. pp.17-21.

Novak, J.M., I., Lima, B. Xing, J.W. Gaskin, C. Steiner, K. Das, M. Ahmedna, D. Rehrah, D.W. Watts and W.J. Busscher. 2009. Characterization of designer biochar produced at different temperatures and their effects on a loamy sand. Ann. Environ. Sci. 3: 195-206.

Vaccari, F.P. 2015. Biochar stimulates plant growth but not fruit yield of processing tomato in a fertile soil. Agric. Ecosyst. Environ. 207: 163-170.

Vakis, N.J. 1990. Evaluation of potato varieties and clones. Miscellaneous Rep. 38, Agric. Res. Inst., Ministry of Agric. And Nat. Resources, Nicosia, Cyprus.

Yang, Y., S. Ma, Y. Zhao, M. Jing, Y. Xu and J. Chen. 2015. A field experiment on enhancement of crop yield by rice straw and corn stalk-derived biochar in Northern China. Sustainability. 7: 1371313725. 
Yilangai, R.M., S.A. Manu, W. Pineau, S.S. Mailumo and K.I. Okekeagulu. 2014. The effect of biochar and crop veil on growth and yield of tomato (Lycopersicum esculentus Mill) in Jos, North central Nigeria. Curr. Agric. Res. 2(1): 37-42.

Yooyen, J., S. Wijitkosum and T. Sriburi. 2015. Increasing yield of soybean by adding biochar. J. Environ. Res. Develop. 9(4): 1066-1074.

Youseef, M.E.A., I.A.S. Al-Easily and D.A.S. Nawar. 2017. Impact of biochar addition on productivity and tubers quality of some potato cultivars under sandy soil conditions. Egypt J. Hort. 44(2): 199 -217.

Zheng, H., Z.Y. Wang, X. Deng, S. Herbert and B. Xing. 2013. Impacts of adding biochar on nitrogen retention and bioavailability in agricultural soil. Geoderma. 206:32-39 